\title{
МЕТАФОРИЧНА МОДЕЛЬ "БІЗНЕС - ЦЕ РУХ" ЯК ЗАСІБ КОНСТРУЮВАННЯ ІМІДЖУ МІЖНАРОДНОЇ КОСМЕТИЧНОЇ КОМПАНІЇ
}

\author{
Орислава Іванців
}

\author{
Тернопільський національний педагогічний університет імені В. Гнатюка, \\ вул. Максима Кривоноса, 2, м. Тернопіль, Украӥна, 46027 \\ orysya_ivantsiv@yahoo.com
}

\begin{abstract}
У статті розкрито особливості метафоричного моделювання як когнітивної основи формування корпоративного іміджу. Описано методику аналізу метафоричних моделей. На основі текстів англомовних прес-релізів міжнародних косметичних компаній виокремлено одну з домінантних метафоричних моделей у сучасному англомовному іміджевому корпоративному дискурсі - "Бізнес - це рух". Здійснено аналіз фреймо-слотової структури зазначеної метафоричної парадигми як засобу конструювання іміджу бізнес-структури. Виявлено прагматичний потенціал метафоричної моделі “Бізнес - це рух”, іiі взаємозв'язок із комунікативною ситуацією та інтенціями учасників комунікативного процесу. Окреслено значення цієї технології мовленнєвого впливу та ефективність її використання в процесі побудови корпоративного іміджу.

Ключові слова: концептуальна метафора, метафорична модель, фреймо-слотова структура, корпоративний імідж, іміджевий корпоративний дискурс.
\end{abstract}

Вступ. У межах когнітивно-дискурсивної парадигми сучасного мовознавства методика метафоричного моделювання набуває особливого значення. Її застосування важливе, зокрема, для дослідження сучасного англомовного іміджевого корпоративного дискурсу, що обслуговує галузь корпоративного іміджмейкінгу - виду професійної діяльності, пов'язаної із формуванням позитивного іміджу компанії. Зазначений дискурс включає увесь адресний потік інформації, забезпечений певною бізнес-структурою, та створюване нею комунікативне поле. Він $є$ повноцінним продуктом мисленнєвомовленнєвої діяльності, який формує необхідні уявлення в цільової аудиторії про суб'єкта економічної діяльності та регулює їі думку стосовно нього.

Процес конструювання іміджу бізнес-структури має когнітивну сутність, оскільки він відображає мисленнєві процеси сприйняття інформації, іiі відбору, систематизації й структурування. Імідж як уявлення про об'єкт виникає у свідомості. Це своєрідне ментальне утворення, тому для його висвітлення доцільно застосовувати інструментарій когнітивної лінгвістики, що дозволить виявити особливості концептуалізації реалій ведення бізнесу, з'ясувати специфіку метафоричного представлення дійсності у сфері економічної діяльності, а також встановити взаємозв'язки між концептуальними метафорами і чинниками, які обумовлюють їхню необхідність. Уже створений імідж, реалізований у тому чи іншому іміджевому повідомленні, постає певним варіантом

(C) Іванців О., 2019 
моделі світу або їі фрагмента, що виявляється на рівні фреймо-слотової структури метафоричних моделей.

Актуальність дослідження визначається необхідністю опису лінгвокогнітивного механізму створення корпоративного іміджу як суттєвого чинника підвищення ефективності діяльності компанії. Мета статті полягає в аналізі структури і прагматичного потенціалу метафоричної моделі “Бізнес-це рух” у контексті побудови корпоративного іміджу.

Аналіз останніх досліджень і публікацій. Теорія метафоричного моделювання розвинулася на основі теорії концептуальної метафори, що виникла в США (Дж. Лакофф, М. Джонсон [14;15]), та теорії регулярної багатозначності, яку розробили російські мовознавці в межах структурно-семантичного опису мовних явищ (Ю. Д. Апресян [1], Й. А. Стернін [9], А. П. Чудінов [11], Д. М. Шмельов [12] та ін.).

Згідно з теорією концептуальної метафори, знання людини про світ структуровані у вигляді ментальних моделей [13]. Поняття “ментальна модель” трактують як структуру репрезентації знань, яка відповідає структурі представленої ситуації та об'єднує інформацію усіх сенсорних систем про те, що є можливим у навколишньому світі $[8$, с. 380$]$.

Однією з головних ментальних моделей, яка бере участь у створенні нового способу представлення й осмислення об’ єкта (явища, сутності), $є$ метафорична модель. Існування метафоричних моделей у психічній сфері людини формує підгрунтя функціонування метафор у мові. Концептуальна метафора знаходить своє вираження в тексті й дискурсі у вигляді метафоричних моделей. У такої моделі широкі можливості мовної реалізації: від традиційного лексико-семантичного варіювання до вибудування тексту або дискурсу $[6$, c. 43$]$.

У цьому дослідженні термін “метафорична модель” використовується для позначення груп концептуальних метафор, об'єднаних однією сферою-джерелом. Метафорична модель тлумачиться як схема зв'язку між понятійними сферами, яка існує або складається у свідомості носіїв мови, і котру можна представити певною формулою: “Х - це Y” [10]. При цьому відношення між компонентами цієї формули потрібно розглядати не як ототожнення, а як уподібнення. Відповідно до згаданої формули система фреймів однієї ментальної сфери слугує основою для моделювання іншої ментальної системи.

Методологія і матеріал дослідження. Матеріалом дослідження послугували 127 текстів англомовних прес-релізів за 2014-2019 роки, розміщених на офіційних веб-сайтах таких міжнародних косметичних компаній, як Avon, Elizabeth Arden, Estée Lauder Companies, Mary Kay та Revlon.

Наша розвідка грунтується на методиці аналізу метафоричних моделей, розробленій А. П. Чудіновим [10], яка включає сім етапів:

1) характеристика вихідної сфери метафоричної експансії (сфери-джерела) понятійної сфери, до якої належать неметафоричні значення охоплених моделлю одиниць;

2) характеристика цільової сфери метафоричного запозичення (сфери-цілі) понятійної сфери, до якої відносяться метафоричні смисли відповідних одиниць моделі;

3) аналіз фреймів, що відносяться до певної метафоричної моделі. Фрейм - це 
структура репрезентації знань, у якій відображено набуту інформацію про певну стереотипну ситуацію й про текст, що іiї описує [8, с. 771];

4) визначення типових слотів, що входять до складу кожного фрейму, тобто елементів ситуації, які включають певну частину фрейму, аспект його конкретизації;

5) виділення компоненту, який пов'язує первинне й вторинне значення одиниць, що охоплені певною метафоричною моделлю;

6) опис дискурсивної характеристики метафоричної моделі, тобто типових для відповідних метафор концептуальних векторів, головних емотивних характеристик і прагматичного потенціалу метафоричної моделі;

7) визначення продуктивності метафоричної моделі, що полягає в ії здатності до розгортання та наявності типових напрямів розгортання в тексті й дискурсі.

Застосування вищеописаної методики дає можливість розкрити когнітивну основу побудови іміджу бізнес-структури та визначити ступінь впливу змін у сфері косметичної індустрії на функціонування англійської мови.

Результати дослідження та їхнє обгрунтування. В сучасному англомовному іміджевому корпоративному дискурсі ми виокремили метафоричну модель “Бізнес - ие рух" як один із основних когнітивних механізмів створення іміджу косметичної компанії. Способи вербалізації транспортної метафори були описані в політичному (Р. Дж. Керімов [4], Х. П. Дацишин [2]) та психоаналітичному дискурсах (Г. М. Коваленко [5]). Метафора “руху” стала об'єктом дослідження Л. В. Надеїнової [7] та І. В. Іванової [3]. За спостереженнями Л. В. Надеїнової, метафоричні образи різних типів руху мають аксіологічне спрямування. Найбільший вплив на оцінку сприйняття руху мають орієнтаційні параметри ситуації переміщення й характер середовища, у якому відбувається пересування предметів [7, с. 6]. На думку І. В. Іванової, метафоричний концепт “рух” має подвійну природу, тому його можна розглядати як онтологічний, так і орієнтаційний [3, с. 21].

Однією з інтерпретацій реалій косметичного бізнесу є їхнє перехрещення 3 номінаціями, пов'язаними з рухом. У такому трактуванні приховане прагнення адресанта показати динаміку змін у сфері косметичної індустрії, запропонувати оцінку темпів реалізації програми діяльності компанії, змалювати шляхи досягнення цілей системи програмних заходів, продемонструвати відстань, яку вдалося подолати, показати міру наближеності до досягнення поставленої мети.

Структуру метафоричної моделі “Бізнес - це рух” формують такі фрейми: “Спосіб пересування”, “Назви доріг, якими здійснюється рух”, “Маршрут пересування”, “Ціль і характер пересування”, “Види подорожей”.

Фрейм "Спосіб пересування"

Метафоричні одиниці цього фрейму представляють образні номінації корпоративної діяльності за допомогою найменувань різних видів руху, пов'язаних із транспортом, $\mathrm{i}$ створюють образне уявлення у свідомості адресата про шляхи розвитку косметичних компаній. Структуру цього фрейму формують наступні слоти.

Слот 1.1. Пересування з використанням транспортних засобів

Матеріал дослідження засвідчує активне використання в англомовному іміджевому дискурсі косметичних компаній концепту “вести” (drive) для образної репрезентації 
рушійних сил ведення бізнесу у відповідній організації, наприклад: At The Estée Lauder Companies, we strongly believe that creativity and innovation drive our success [18]. Для косметичної компанії Estée Lauder цими рушіями $є$ креативність та інноваційність.

Окрім того, для метафоричного змалювання високого злету, якого вдалося досягнути продукції компанії на ринку косметичних товарів, використовується вираз “злітати на ракеті" (rocket): Even Better Clinical Dark Spot Corrector rocketed to stardom, becoming the brand's bestseller in less than a year... [18].

Іміджмейкери метафорично представляють косметичну компанію Tiny Tillia як таку, що переміщує (transports) ciм'ї у фантастичний світ чудес задля підвищення iii авторитету в індустрії краси, що яскраво проілюстровано в наступному прикладі: Transporting families to a warm, whimsical world of wonder. Tiny Tillia adds fanciful fun to mom and baby's daily routine with toys, bath and clothing products for baby as well as beauty must-haves and accessories for mom [16].

Слот 1.2. Пересування без використання транспортних засобів

Рух дорогою можливий не лише за допомогою транспортного засобу, але й пішки. Метафоричне освоєння концепту “ходьба" (walk) у досліджуваному дискурсі здійснюється для маніфестації одного з благодійних проектів косметичної компанії Avon, пов'язаного з проведенням пішої ходи й спрямованого на покращення інформованості жінок усього світу щодо небезпеки та методів профілактики раку молочної залози: In 2005, the company started the Avon Walk Around the World For Breast Cancer series, bringing grassroots activism to a global scale [16].

Для образної репрезентації косметичної продукції компанії використовується метафоричний вираз “долати відстань” (go the distance). Це сприяє створенню уявлення в адресата, що нанесений макіяж з використанням цих косметичних засобів буде мати довготривалий ефект: Makeup that Goes the Distance [16].

Фрейм "Назви доріг, якими здійснюється рух"

У цьому фреймі на передній план виходять концепти “дорога" (road) й "шлях" (way). Адресату пропонується розглядати діяльність керівників і працівників компанії як дорогу, по якій вони йдуть самі, або прямує організація, у якій вони працюють. Це дає змогу створити ефект безперервного руху, дієвої роботи компанії щодо досягнення стратегічних цілей, що постійно набирає обертів, наприклад: The world has gone digital, and The Estée Lauder Companies is leading the way by investing in dynamic digital and social tools to help employees collaborate, share ideas and work more efficiently [18]; "We applied this same, deep-rooted commitment to searching for a new Mary Kay Career Car option ... to inspire the Mary Kay independent sales force on their road to success ...," said Yvette Franco, Vice President of U.S. Marketing [19].

На шляху до успіху в бізнесовій діяльності часто з'являються перепони, що яскраво проілюстровано в такому прикладі: Ultimately, there were some bumps along the road to success, and this amazing entrepreneur headed out on her own [19].

Крім того, сучасний англомовний іміджевий корпоративний дискурс фіксує метафоричне використання концепту “стежка” (path) для змалювання шляху, який доводиться проходити жінкам для покращення вигляду їхньої шкіри: ... the Elizabeth Arden Visible Difference collection is ideal to start you on the path toward a more beautiful complexion [17]. 


\section{3. Фрейм "Марирут пересування"}

Прокладання маршруту передбачає визначення напряму руху (direction) об'єкта певною територією: “... we're leading the prestige beauty industry in a new direction, " said William P. Lauder Executive Chairman [18]. У цьому висловленні іміджмейкери експлуатують метафору “руху” задля запевнення реципієнта повідомлення в тому, що інноваційна діяльність компанії спричинила зміну напряму розвитку косметичної індустрії. Це сприяє створенню образу організації-новатора на міжнародному ринку парфумерно-косметичних товарів.

Переміщення за певним маршрутом передбачає також можливість подолання проміжних етапів відстані, що відповідають запланованій послідовності кроків (steps): The first step in any daily regimen is cleansing [17]; Foundation can put the perfect finish on your complexion ... [17]. У цих фрагментах дискурсу щоденний догляд за шкірою осмислюється як черговість кроків на шляху до досягнення хороших результатів.

Фірмовий салон-магазин від косметичної компанії постає в досліджуваному дискурсі як місце призначення (beauty destination) для шанувальників краси: Revlon set up a fun, interactive beauty destination in Soho at the rag \& bone store on Mercer Street [20].

4. Фрейм "Ціль і характер пересування"

Структуру цього фрейму формують наступні слоти: “Ціль руху”, “Характер руху”, “Похідне спорядження".

Слот 4.1. Ціль руху

Будь-яке пересування територією спричинене певною метою. У косметичній індустрії діяльність та розвиток компаній теж визначається відповідно до їхніх корпоративних цілей (goals), що яскраво проілюстровано в наступних прикладах: Mary Kay was founded in 1963 by Mary Kay Ash with the goal of helping women achieve personal growth and financial success [19]. Як бачимо, головними цілями косметичної компанії Mary Kay є надання допомоги жінкам у досягненні фінансового успіху та особистого зростання.

Слот 4.2. Характер руху

Косметичні компанії швидко рухаються вперед (move forward very fast), ідучи в ногу (be up to speed) із сучасними модними тенденціями. В іншому випадку вони можуть просто заблукати (get lost in the shuffle), як це видно з такого текстового фрагменту: "... If a cosmetics company doesn't move fast, it can get lost in the shuffle. It is essential that a company specializing in beauty is up to speed with the current trends in fashion ..., " says Tom Pecheux [18].

За спостереженнями I. В. Іванової, стрімкість дій свідчить про схильність до новаторства, а розміреність і непоспішність - про здатність переконливо іти за визначеним курсом [3, с. 22].

Для задоволення високих очікувань жінок косметична компанія Elizabeth Arden іде в ногу (keер up the pace) з потребами й вимогами цієї гендерно-специфічної демографічної групи: Elizabeth Arden knows this only too well and has kept up the pace with the needs and demands of this huge gender specific demographic with particularly high expectations [17]. 
Слот 4.3. Похідне спорядження

Переміщення певною територією передбачає наявність відповідного спорядження ((карти (roadmap), компаса (guiding compass) тощо)) для кращого орієнтування в просторі та часі. Такі дороговкази притаманні й компаніям у сфері косметичної індустрії, які слугують засобами досягнення комерційного успіху, наприклад: “Our belief in our purpose has been our guiding compass for 125 years, and it will remain our roadmap for the future," said Avon Products, Inc. Chairman and Chief Executive Officer Andrea Jung [16].

5. Фрейм “Види подорожей”

Аналіз фактичного матеріалу засвідчив активне використання концептів “подорож” (journey) та “поїздка" (trip) для метафоричного переосмислення корпоративних реалій в індустрії краси. Між цими термінами існує принципова відмінність на рівні конотацій. Journey вживається для позначення довгої, нелегкої подорожі, у той час як trip може означати короткочасну поїздку з метою розваги.

Шлях до досягнення стратегічних цілей компанії не буває легкий, часто виникає чимало труднощів. Тому цей процес знаходить образне вираження в метафоричному використанні лексеми јоurney, наприклад: As we pursue our strategic journey, we're investing greater resources in our most promising opportunities - by category, brand, region and channel [18].

У наступному фрагменті дискурсу використання парфумерної продукції від компанії Elizabeth Arden осмислюється як миттєва подорож (trip) до сільської місцевості теплого літнього дня: A fresh feminine floral bouquet with spicy woody undertones, opening a bottle of blue grass is like an instant trip to the countryside on a warm summer day [17].

У 2011 році міжнародна косметична компанія Avon проводила всесвітній тур під назвою Avon Believe World Tour для відзначення іiї спадщини й віри в місію збагачувати життя жінок. Під час цього туру (tour) було здійснено зупинки (stops) у найбільших містах світу, що проілюстровано в наступному фрагменті: Throughout 2011, approximately 125,000 Avon Representatives will participate in the Avon Believe World Tour as it makes global stops in London, Istanbul, New York, Chicago ... [16].

Як бачимо з вищенаведених прикладів, метафора “руху” містить образи, які об’єднують концептуальні вектори розвитку та динаміки.

Висновки та перспективи подальших досліджень. Таким чином, актуалізована в межах іміджевого дискурсу косметичних компаній метафорична модель “Бізнес - це рух" є детально структурована та має виразне комунікативно-прагматичне спрямування. Використання цієї моделі у зазначеному дискурсі сприяє формуванню й підсиленню у свідомості цільової аудиторії відчуття розвитку компаній, безперервного руху, ефективної роботи злагодженого колективу, векторної спрямованості дій керівництва та неодмінно позитивного результату цих дій, що дозволяє створити позитивний імідж компанії. Подальші наукові пошуки можна спрямувати на опис інших метафоричних моделей в сучасному англомовному іміджевому корпоративному дискурсі. 


\section{СПИСОК ВИКОРИСТАНОЇ ЛІТЕРАТУРИ}

1. Апресян Ю. Д. О регулярной многозначности / Ю. Д. Апресян // Известия АН СССР. Серия литературы и языка. - М., 1971. - № 6. - С. 509-523.

2. Дацишин X. П. Метафора в українському політичному дискурсі (за матеріалами сучасної періодики) : дис. ... канд. філол. наук : 10.01 .08 / Дацишин Христина Петрівна. -Иванова И. В. Концептуальная метафора как средство формирования образа политического деятеля в англоязычной прессе : автореф. дис. на соискание ученой степени канд. филол. наук : спец. 10.02.04 "Германские языки" / И. В. Иванова. - М., 2004. - 24 с.

3. Керимов Р. Дж. Артефактная концептуальная метафора в немецком политическом дискурсе : автореф. дис. на соискание ученой степени канд. филол. наук : спец. 10.02.04 “Германские язики" / Р. Дж. Керимов. - Кемерово, 2005. - 186 с.

4. Коваленко Г. М. Метафора руху в англомовному психоаналітичному дискурсі / Г. М. Коваленко // Лінгвістика XXI століття : нові дослідження і перспективи. - К. : Логос, 2010. - С. 131-137.

5. Мишанкина H. A. Метафорические модели лингвистического дискурса / Н. А. Мишанкина // Вестник ТГУ. Серия : Филология. - Томск, 2009. - № 324. - С. 41 49.

6. Надеина Л. В. Семантика движения в отражении русской языковой диалектной метафоры : автореф. дис. на соискание ученой степени канд. филол. наук : спец. 10.02.01 “Русский язик" /Л. В. Надеина. - Томск, 2007. - 25 с.

7. Селіванова О. О. Лінгвістична енциклопедія / О. О. Селіванова. - П. : Довкілля-К, 2011. - $844 \mathrm{c}$.

8. Стернин И. А. Лексическое значение слова в речи / И. А. Стернин. - Воронеж : Изд-во Воронеж. ун-та, 1985. - $171 \mathrm{c.}$

9. Чудинов А. П. Метафорическая мозаика в современной политической коммуникации [Электронный ресурс] / А. П. Чудинов. -Чудинов А. П. Регулярное семантическое варьирование в русской глагольной лексике : дис. ... доктора филол. наук : 10.02.01 / Чудинов Анатолий Прокопьевич. - Свердловск, 1990. - 348 с.

10. Шмелев Д. Н. Проблемы семантического анализа лексики (на материале русского языка) / Д. Н. Шмелев. - М. : Наука, 1973. -Johnson-Laird P. N. Mental models / P. N. Johnson-Laird. - Cambridge, MA : Harvard University Press, 1983.

11. Lakoff G. Metaphors We Live By / G. Lakoff, M. Johnson. - Chicago : University of Chicago Press, 1980. - 242 p.

12. Lakoff G. The contemporary theory of metaphor / G. Lakoff // Metaphor and Thought. Cambridge, 1993. - P. 202-252.

\section{СПИСОК ВИКОРИСТАНИХ ДЖЕРЕЛ}

13. Avon Products Media Centre [Electronic resource]. - Access mode: http://media.avoncompany.com/index.php.

14. Elizabeth Arden [Electronic resource]. - Access mode: http://www.elizabetharden.com.

15. Estée Lauder Companies Press Releases [Electronic resource]. - Access mode: http://www. elcompanies.com/Pages/Press-Releases.aspx.

16. Mary Kay Press Room [Electronic resource]. - Access mode: http://www.marykay.com/enUS/About-Mary-Kay/PressRoom.

17. Revlon [Electronic resource]. - Access mode: http://www.revlon.com. 


\section{REFERENCES}

1. Apresjan Ju. D. O reguljarnoj mnogoznachnosti [About regular polysemy] / Ju. D. Apresjan // Izvestija AN SSSR. Serija literatury i jazyka. - M., 1971. - № 6. - S. 509-523.

2. Datsyshyn Kh. P. Metafora v ukrainskomu politychnomu dyskursi (za materialamy suchasnoi periodyky) [Metaphor in the Ukrainian political discourse (based on modern press] : dys. ... kand. filol. nauk : 10.01.08 / Datsyshyn Khrystyna Petrivna. - Lviv, 2004. - 208 s.

3. Ivanova I. V. Konceptual'naja metafora kak sredstvo formirovanija obraza politicheskogo dejatelja $\mathrm{v}$ anglojazychnoj presse [Conceptual metaphor as a means of politician's image formation in the English-language press] : avtoref. dis. na soiskanie uchenoj stepeni kand. filol. nauk : spec. 10.02.04 "Germanskie jazyki" / I. V. Ivanova. - M., 2004. - 24 s.

4. Johnson-Laird P. N. Mental models / P. N. Johnson-Laird. - Cambridge, MA : Harvard University Press, 1983.

5. Kerimov R. Dzh. Artefaktnaja konceptual'naja metafora v nemeckom politicheskom diskurse [Artefact conceptual metaphor in German political discourse] : avtoref. dis. na soiskanie uchenoj stepeni kand. filol. nauk : spec. 10.02.04 "Germanskie jaziki” / R. Dzh. Kerimov. Kemerovo, 2005. - $186 \mathrm{~s}$.

6. Kovalenko H. M. Metafora rukhu v anhlomovnomu psykhoanalitychnomu dyskursi [Metaphor of movement in the English-language psychoanalytic discourse] / H. M. Kovalenko // Linhvistyka KhKhI stolittia : novi doslidzhennia i perspektyvy. - K. : Lohos, 2010. S. 131-137.

7. Lakoff G. Metaphors We Live By / G. Lakoff, M. Johnson. - Chicago : University of Chicago Press, 1980. - 242 p.

8. Lakoff G. The contemporary theory of metaphor / G. Lakoff // Metaphor and Thought. Cambridge, 1993. - P. 202-252.

9. Mishankina N. A. Metaforicheskie modeli lingvisticheskogo diskursa [Metaphorical models of linguistic discourse] / N. A. Mishankina // Vestnik TGU. Serija : Filologija. - Tomsk, 2009. - № 324. - S. 41-49.

10. Nadeina L. V. Semantika dvizhenija $v$ otrazhenii russkoj jazykovoj dialektnoj metafory [Semantics of movement in the reflection of the Russian-language dialectal metaphor] : avtoref. dis. na soiskanie uchenoj stepeni kand. filol. nauk : spec. 10.02.01 "Russkij jazik" /L. V. Nadeina. - Tomsk, 2007. - 25 s.

11. Selivanova O. O. Linhvistychna entsyklopediia [Linguistic encyclopedia] / O. O. Selivanova. - P. : Dovkillia-K, 2011. - 844 s.

12. Sternin I. A. Leksicheskoe znachenie slova $\mathrm{v}$ rechi [Lexical meaning of a word in speech] / I. A. Sternin. - Voronezh : Izd-vo Voronezh. un-ta, 1985. - $171 \mathrm{~s}$.

13. Chudinov A. P. Metaforicheskaja mozaika v sovremennoj politicheskoj kommunikacii [Metaphorical mosaic in modern political communication] [Jelektronnyj resurs] / A. P. Chudinov. - Ekaterinburg : Ural'skij gumanitarnyj institut, 2003. - 118 s. - Rezhim dostupa: http:// www.ahmerov.com/book 468.html

14. Chudinov A. P. Reguljarnoe semanticheskoe var'irovanie v russkoj glagol'noj leksike [Regular semantic variation in Russian verbal vocabulary] : dis. ... doktora filol. Nauk : 10.02.01 / Chudinov Anatolij Prokop'evich. - Sverdlovsk, 1990. - 348 s.

15. Shmelev D. N. Problemy semanticheskogo analiza leksiki (na materiale russkogo jazyka) [Problems of the semantic analysis of vocabulary (based on the Russian language)] / D. N. Shmelev. - M. : Nauka, 1973. - 279 s. 


\title{
SOURCES
}

16. Avon Products Media Centre [Electronic resource]. - Access mode: http://media.avoncompany.com/index.php.

17. Elizabeth Arden [Electronic resource]. - Access mode: http://www.elizabetharden.com.

18. Estée Lauder Companies Press Releases [Electronic resource]. - Access mode: http://www. elcompanies.com/Pages/Press-Releases.aspx.

19. Mary Kay Press Room [Electronic resource]. - Access mode: http://www.marykay.com/enUS/About-Mary-Kay/PressRoom.

20. Revlon [Electronic resource]. - Access mode: http://www.revlon.com.

Стаття надійшла до редколегї 29.09.2019

Прийнята до друку 15.11.2019

\section{METAPHORICAL MODEL "BUSINESS IS MOVEMENT" AS A MEANS OF THE INTERNATIONAL COSMETIC COMPANY'S IMAGE CONSTRUCTION}

\section{Oryslava Ivantsiv}

\author{
Ternopil Volodymyr Hnatiuk National Pedagogical University, \\ 2, M. Kryvonosa Str., Ternopil, Ukraine, 46027 \\ orysya_ivantsiv@yahoo.com
}

The article focuses on analysing the structure and pragmatic potential of one of the major metaphorical models in the cosmetic industry's corporate discourse of image-making - "Business is movement". The research data includes an electronic corpus of 127 press releases issued by five international cosmetic companies, namely Avon Products, Elizabeth Arden, Estee Lauder Companies, Mary Kay and Revlon between 2014 and 2019 and downloaded from the company's websites.

Within the cognitive and discursive paradigms of today's linguistics, the methodology of metaphorical modelling is noticeably growing in importance. It is particularly significant for corporate image-making since the procedure of company's image construction is cognitive in its nature, reflecting the mental processes of information perception, selection, systematisation, and structuring.

According to the theory of conceptual metaphor, human knowledge about the world is structured in the form of mental models. One of the basic mental models involved in the creation of a new way of presenting and interpreting an object is a metaphorical model. This term is used for designating a group of conceptual metaphors united by one source domain. Our research is based on the methodology of the metaphorical model analysis developed by A. P. Chudinov, which consists in the description of the model's frame-slot structure.

Data analysis shows that one of the most frequently used metaphorical models in the cosmetic industry's corporate discourse of image-making is "Business is movement", which presents the conceptual vector of development and dynamics. In the texts of corporate press releases, this metaphorical cluster contributes to the formation of the sense of the companies' development, continuous movement, dynamics of changes in the international cosmetic market, efficient work of a well-coordinated team, purposeful management actions, and positive result of these actions in the minds of the target audience. It allows image-makers to develop a powerful image of the cosmetic company that moves forward to achieve its goals and meet the needs and expectations of the consumers.

Key words: conceptual metaphor, metaphorical model, frame-slot structure, corporate image, corporate discourse of imagemaking. 